\title{
Characterization of incineration residues from wastewater treatment plant in Polish city: a future waste based source of valuable elements?
}

\author{
Monika Kasina $^{1}$ (D $\cdot$ Małgorzata Wendorff-Belon ${ }^{1} \cdot$ Piotr Rafał Kowalski $^{1} \cdot$ Marek Michalik $^{1}$
}

Received: 4 June 2018 / Accepted: 12 February 2019 / Published online: 28 February 2019

(C) The Author(s) 2019

\begin{abstract}
To support the rational management of raw materials in the European Union more attention is being paid to the resource potential of waste materials, which are increasing in volume due to industrial development and the world population growth. One of the methods to reduce the amount of produced and landfilled waste is incineration. As a result of sewage sludge incineration, fly ash (ISSA - incinerated sewage sludge ash) and APC (air pollution control) residues are produced. The goal of this study was to characterize incineration residues from waste water treatment plant in Polish city with ca. one million inhabitants using mineralogical, chemical methods, and to estimate the recovery potential of valuable components. Both incineration products accumulate elements which are of valuable concentrations, such as $\mathrm{P}\left(17 \mathrm{wt} \%\right.$ of $\mathrm{P}_{2} \mathrm{O}_{5}$ on average in the ISSA), as well as significant amounts of metals such as $\mathrm{Zn}, \mathrm{Pb}, \mathrm{Cu}, \mathrm{Ni}$, and $\mathrm{Cr}$. Small particle sizes $<125 \mu \mathrm{m}$ in both materials favor the accumulation of elements of higher volatility during incineration, but they are usually dispersed within a matrix, main minerals or amorphous substance, or are present in the form of micro inclusions or grains $<10 \mu \mathrm{m}$, which thus excludes their easy recovery.
\end{abstract}

Keywords Sewage sludge incineration $\cdot$ ISSA $\cdot$ APC residues $\cdot$ Metallic elements $\cdot$ Phosphates

\section{Introduction}

Resource depletion and the implementation of the circular economy principles, where mineral resources are preserved and valuable products and materials are reused and recycled for as long as possible, as well as rising environmental awareness have caused waste management to become a major social and economic issue in the development of a sustainable economy [14]. There is a strong emphasis on looking for a source of valuable elements in alternative resources, such as waste streams. In the near future, waste landfilling will become more expensive than other methods of waste treatment; thus, the European Union's (EU) Member States have committed to a significant reduction in the amount of landfilled waste, and to use its inherent energy and waste-based raw material potential. Recently, waste incineration is considered to be one of the most reasonable options to fulfill these commitments. The process deals with

Monika Kasina

monika.kasina@uj.edu.pl

1 Institute of Geological Sciences, Jagiellonian University, Gronostajowa 3a, 30-387 Krakow, Poland different types of waste, with proper calorific value to sustain an autothermic incineration reaction. The process of thermal treatment is applicable to municipal, medical and industrial wastes and residues from wastewater treatment $[3,5,15,33]$.

Over the past decades, a significant development in waste incineration technology in the EU was noted. The main focus was on the reduction of the emission of gas and suspended particles, and on reducing the operating cost of the installation, as well as achieving a significant reduction in the amount of landfilled wastes to $50 \%$ already in 2009 and to $35 \%$ in 2016 in comparison to the amount from the 1995 . Germany, the Netherlands, Sweden, Austria, Denmark and Belgium reached these goals by 2010 through the combination of recycling technology, biological waste treatment and energy recovery during waste thermal transformation [7].

The amount of municipal waste, which are landfilled in Poland is slowly but systematically decreasing, from $74 \%$ in 2010 to $57 \%$ in 2014. Despite this improvement, the volume is still almost twice that of the landfilled municipal waste in EU countries ( 30\%) where the waste management system is well developed. In the EU countries in 2014, on average $\sim 27 \%$ of municipal waste was incinerated, while in Poland this was $\sim 15 \%$, which is a significant increase 
compared to 2010 , when $<1 \%$ of municipal waste was thermally treated.

Population growth causes an increase in the amount of sewage sludge produced as a result of wastewater treatment, which is one of the types of waste generated in the EU in huge quantities [27], presenting challenges for its proper management. It is estimated that by the year 2020, 13 million tons of sewage sludge will be produced annually in the EU countries [38].

Municipal wastewater is a mixture of water from households, small industrial plants, trading and service facilities, and sometimes rainwater depending on the rainfall, which depending on the rainfall intensity can cause a flush of mineral and organic pollutants into the storm sewers $[13,18]$. Therefore, sewage sludge obtained as a result of wastewater treatment is considered as a sink for different contaminants and mineral fraction suspended in water. The main purpose of incineration is to reduce mass, volume and the potential negative influence of sewage sludge on the environment through disinfection and detoxification at high temperatures. As a result of sewage sludge incineration, significant amounts of energy are recovered due to its relatively high calorific value (ca. 12-16 $\mathrm{MJ} \mathrm{Kg}^{-1} \mathrm{kcal} \mathrm{kg}^{-1}$ ) [12, 26], which enables a waste-to-energy strategy to be followed.

Sewage sludge often accumulates metals (e.g. $\mathrm{Zn}, \mathrm{Cu}, \mathrm{Ni}$, $\mathrm{Cd}, \mathrm{Pb}, \mathrm{Hg}, \mathrm{Cr}$, and $\mathrm{Sb}$ ) [15] that are present in wastewater and suspended solid pollutants. For this reason, the direct utilization of sludge in agriculture is excluded, since this would not fulfill the requirements of European legislation [35] or national norms; therefore, sludge in agriculture could be excluded (Fig. 1). Interestingly, the application of sewage sludge in plant cultivation intended for compost production has remained at a similar high level since 2014 (Fig. 1).

Sewage sludge was landfilled for many years, and in developing countries this way of dealing with sludge is still commonplace; however, in the long term, landfilling of this material can negatively affect surface and ground water or soils, since it is known that sewage sludge contains non-biodegradable compounds containing heavy metals, toxic organic substances and parasites, pathogens and microorganisms. In Poland, the increasing amount of sewage sludge is currently thermally treated, whereas landfilling is being highly reduced (Fig. 1).

As a result of sewage sludge incineration, a variety of solid residues (ISSA and APC residues) and technological wastes (flue gas with suspended dust, wastewater, and used material from the fluidized bed in the boiler) are produced. A significant reduction of sewage sludge mass (70\%) and volume (90\%) after thermal treatment [4, 23] leads to a concentration of numerous elements in the solid residues, including potentially valuable components. These residues can be considered, for example, as a source of metallic elements that can have industrial applicability, or as hazardous material, and thus after thermal treatment sewage sludge should be stabilized before any further application.

The goal of this study was to characterize the ISSA and the APC residues formed as a result of sewage sludge thermal treatment obtained from an incineration plant located in the southern Poland using mineralogical and chemical methods, and to estimate the recovery potential of components that can be considered as alternative resources of industrially valuable elements and rare earth elements (REE) based on the data obtained from this incineration plant over 1 year.
Fig. 1 The management of solid sewage sludge in Poland over the 2005-2015 period (Statistical Yearbook of the Republic of Poland 2016)

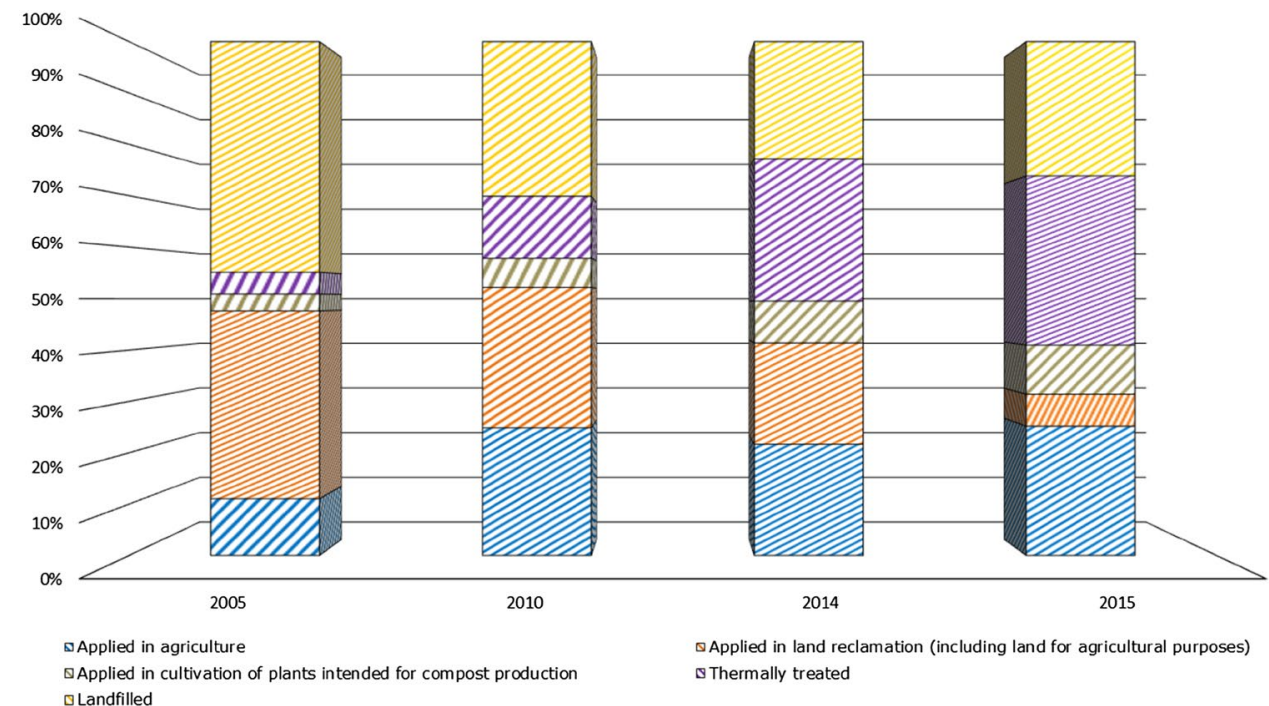




\section{Materials and methods}

\section{Fluidized-bed incineration of sewage sludge}

To enable the autothermic incineration of sewage sludge, the excess moisture has to be removed. The partly dewatered sludge, from the wastewater treatment plant that contain $23 \%$ of the dry mass, is transported to the drying node for the sludge membrane drying system, where the sludge is dried down to $36 \%$ of the dry mass (solid content; using disc dryerHaarslev). The dryer is equipped with a heating medium in the form of saturated steam, which is produced in a steam boiler or economizer, using the heat recovered in the sludge incineration process. This process takes place under low negative pressure. The dried sludge is incinerated in a fluidized-bed boiler (Pyrofluid ${ }^{\mathrm{TM}}$ ) that provides high turbulence for the fluidized bed at a constant intensity throughout the process to ensure the complete incineration of organic matter and a stable operating temperature in the range of $850-900{ }^{\circ} \mathrm{C}$, which ensures a longer life of the boiler. In addition, the heat exchange area within the fluidized bed allows the size of the installation to be reduced. The thermal utilization station is equipped with a heat exchanger, which is responsible for the pre-cooling of flue gases and the production of saturated steam to power the drying node. Fluidization is obtained by the insertion of an inert material, namely silica sand. It is achieved by introducing an air stream into the bed at pressure, which causes the liquid in the bed to be brought to boiling point [16]. Dewatered sludge is pumped into the boiler and dried out. As a consequence of the turbulence streams in the fluidized bed, the sludge disintegrates [35]. As a result of the incineration, organic matter is combusted and heat-resistant solids and volatile components are carried out in the exhaust gas. Heavier components and incombustible fraction are separated in a multicyclone, captured on an electrostatic precipitator and transported in the form of ISSA into the ash silo, whereas the lighter components and flue gas cleaning products (APC residues) are caught up in a bag filter after reactant addition and subjected to further processing [16]. In the flue gas purification process $\mathrm{NaHCO}_{3}$ is added. Uncaptured suspended particles in the flue gases are emitted through the chimney into the atmosphere. The flue gases are continuously monitored to measure the content of the suspended particles and gas composition (PM10, $\mathrm{CO}, \mathrm{NO}_{\mathrm{x}}$, $\mathrm{NH}_{3}, \mathrm{HCl}, \mathrm{HF}, \mathrm{C}_{\mathrm{org}}$, and $\mathrm{SO}_{2}$, as well as the elements $\mathrm{Cd}$, Ta, $\mathrm{Hg}, \mathrm{Sb}, \mathrm{As}, \mathrm{Pb}, \mathrm{Cr}, \mathrm{Co}, \mathrm{Cu}, \mathrm{Mn}, \mathrm{Ni}$, and $\mathrm{W}$ ) to control the emissions to the atmosphere with accordance to the 2000/76/ EC directive [9].

\section{ISSA and APC residues}

The ISSA is classified as non-hazardous waste in accordance to the European List of Waste (Commission Decision
2000/532/EC and Annex III to Directive 2008/98/EC) with waste code 190114 ISSA other than those mentioned in 19 $011^{*}$, i.e. ISSA containing dangerous substances. Product from the cleaning of flue gases (so called APC residue) is classified as hazardous waste in accordance to the European List of Waste (Commission Decision 2000/532/EC and Annex III to Directive 2008/98/EC) with waste code 1901 07* ("solid waste from gas treatment").

The ISSA (FA1-4) and the APC residues (APC1-4) samples were collected from sewage sludge incineration plants located in an urban agglomeration with ca. one million inhabitants. Sampling was performed quarterly for a 1-year period, starting in December 2015 (for details see Table 1). During each sampling, ca. $10 \mathrm{~kg}$ of the averaged ISSA and $5 \mathrm{~kg}$ of the APC residues were collected from the silo during chutes to the transporting trolleys. Since the ISSA and the APC residues are different, macroscopically differences in their composition were expected.

Due to a high content of water soluble phases in the APC residues, a soluble fraction was removed, precipitated and studied mineralogically. The averaged $1 \mathrm{~kg}$ of material was dissolved with $20 \mathrm{~L}$ of deionized water and filtrated, which as a consequence caused an APC residues' mass reduction of $98 \%$. The residual non-soluble fraction was also investigated.

\section{Methods}

The granulometric composition was measured using a Mastersizer 3000 equipped with a Malvern Hydro EV detector. Prior to the analyses, the ISSA and the APC residues were averaged and passed through a sieve with a mesh size of $1.5 \mathrm{~mm}$ to obtain $100 \mathrm{~g}$ of each sample. After dispersion in deionized water, each sample was measured three times.

Chemical analysis using inductively coupled plasma mass spectrometry (ICP-MS) and inductively coupled plasma atomic emission spectroscopy (ICP-AES) were performed by Bureau Veritas Minerals (formerly AcmeLabs Analytical Laboratories) in Vancouver, Canada. These analyses allowed the content of major and trace elements to be determined, respectively, as well as the content of valuable components

Table 1 Samples type and sampling time

\begin{tabular}{llll}
\hline & Sample type & Sample name & Date of sampling \\
\hline 1 & Fly ash (ISSA) & FA1 & 27 November 2015 \\
2 & & FA2 & 31 March 2016 \\
3 & & FA3 & 14 July 2016 \\
4 & & FA4 & 18 November 2016 \\
5 & Air pollution control & APC1 & 27 November 2015 \\
6 & (APC) residue & APC2 & 31 March 2016 \\
7 & & APC3 & 14 July 2016 \\
8 & & APC4 & 18 November 2016 \\
\hline
\end{tabular}


including metallic elements. The $\mathrm{C}_{\text {tot }}$ and $\mathrm{S}_{\text {tot }}$ content were measured using LECO combustion analysis and loss on ignition (LOI) was obtained using the thermal methods.

Qualitative powder X-ray diffraction analyses (XRD) were performed to obtain information on the phase composition of the ISSA and the APC residues using a Philips X'Pert diffractometer (type APD, also used for quantitative measurements), with a goniometer PW 3020 (angle range of $2-70^{\circ} 2 \Theta$ with a step of $\left.0.02^{\circ} 2 \mathrm{~s}^{-1}\right)$. To identify the phase composition, Philips X'Pert software (associated with the ICDD database) was used. For the analyses, the samples were milled manually in an agate mortar. To quantify the contribution of the individual components of the crystalline and amorphous phases in these materials, quantitative XRD analyses were performed. Interpretation was based on calculations using SIROQuant software packages (Sietronics Pty Ltd). Prior to the qualitative XRD analyses, averaged samples were milled dry in an agate mill, while for the quantitative analyses $2.7 \mathrm{~g}$ of the sample with the addition of $\mathrm{ZnO}(0.3 \mathrm{~g})$ as the internal standard was milled in ethanol for 10 min using a McCrone micronizing mill (Glen Creston). Measurements were performed using disoriented specimens at an angle range of $2-70^{\circ} 2 \Theta$ with a step of $0.02^{\circ} 5 \mathrm{~s}^{-1}$.

Organic matter analysis was performed for a selected sample of the APC residues and one of the ISSA samples that contained the highest $\mathrm{C}_{\text {tot }}$ content. Approximately, $50 \mathrm{~g}$ of each sample was extracted using ultrasonic agitation for three 20 min periods in $300 \mathrm{ml}$ of dichloromethane (DCM) and methanol mixture (1:1 vol; all solvents spectroscopically pure). The solvent extracts were separated from the residues in the centrifuge, and then carefully concentrated by rotary evaporator and transferred to pre-weighed glass vials. Total extracts were converted before gas chromatography-mass spectrometry (GC-MS) analysis to trimethylsilyl derivatives by reaction with BSTFA [N,O-bis-(trimethylsilyl)trifluoroacetamide] dissolved in super-dehydrated DCM and heated at $70{ }^{\circ} \mathrm{C}$ for $3 \mathrm{~h}$ [28].

GC-MS analysis of the derivatized extracts was performed with an Agilent 7890A chromatograph equipped with an EPC Cool On-Column Inlet and fitted with a fused silica capillary column $(60 \mathrm{~m} \times 0.32 \mathrm{~mm})$ coated with HP-5 MS (0.25 $\mu \mathrm{m}$ film thickness). Helium was used as a carrier gas and the samples were injected into the column at $40{ }^{\circ} \mathrm{C}$. The oven temperature was kept constant for $3 \mathrm{~min}$, increased up to $120^{\circ} \mathrm{C}$ at $20^{\circ} \mathrm{C}$ per min, then increased to $300{ }^{\circ} \mathrm{C}$ at $3{ }^{\circ} \mathrm{C}$ per min and maintained at that temperature for $60 \mathrm{~min}$. The chromatograph was coupled to an Agilent 5975C Network with mass selective detector operated with an ion source temperature set at $200{ }^{\circ} \mathrm{C}$, ionisation energy $70 \mathrm{eV}$ and a cycle time of $1 \mathrm{~s}$ in the scan range of $\mathrm{m} / \mathrm{z} 50-700$. Compound identifications were based on comparison with the literature mass spectra and those from the Wiley Registry of Mass Spectral Data (7th ed.).
Detailed microscopic studies were performed using a Hitachi S-4700 field emission scanning electron microscope (FE-SEM) combined with a Noran energy dispersive spectrometer (EDS). These studies enabled determination of the chemical composition of the phases, including those that are below the threshold of detection of the XRD method using the spot or micro-area analytical modes. The detailed characteristics of the studied minerals based on chemical analysis of the components were analyzed, as well as determination of the relationship between them, their forms of occurrence and research on the metallic elements occurring in various forms within the crystalline and amorphous phases, present in the form of grains and micro-grains' alloys and dispersed metallic inclusions. The ISSA and the APC residues, prepared as both polished thin sections and as grains mounted on carbon discs, were coated with carbon or gold. Analyses were performed at accelerating voltage $20 \mathrm{kV}$ and beam current $10 \mathrm{~mA}$, using the secondary electron (SE) and backscattered electron (BSE) imaging modes.

\section{Results and discussion}

\section{Incineration residues composition}

Out of 76,374 tonnes of dewatered sludge (100 wt \%) incinerated in 2015 in the studied installation, 4,452 tonnes of the ISSA ( $6 \mathrm{wt} \%), 836$ tonnes of the APC residues ( $1 \mathrm{wt} \%$ ) and 0.14 tons of suspended particles in flue gas $(0.0002 \mathrm{wt} \%)$ (not discussed in this study due to the very low content) were produced (Fig. 2). Incineration caused 93\% mass reduction of input sewage sludge and concentration of elements including those that can be considered both as potentially valuable metallic components and also as potentially hazardous.

\section{Chemical and mineralogical characterization of sewage sludge incineration residues}

The ISSA is a reddish, fine material, where on average $63 \mathrm{vol} \%$ of particles are below $100 \mu \mathrm{m}$. The particle size distribution is unimodal (Fig. 3a) with a mode at $98 \mu \mathrm{m}$ for samples FA3 and FA4, modes between 46 and $67 \mu \mathrm{m}$ in sample FA1, and between 67 and $98 \mu \mathrm{m}$ in sample FA2. The soluble material content in the ISSA is around $1 \mathrm{wt} \%$. The particle size distribution is an important characteristic that can not only influence the distribution and accumulation of elements, but also the planning of processing methods.

The results of the chemical analyses were averaged after four sampling campaigns (Table 2). The ISSA is an $\mathrm{Si}-\mathrm{Fe}-\mathrm{Ca}-\mathrm{P}-\mathrm{Al}$ dominated material with very low content of $\mathrm{Na}, \mathrm{K}, \mathrm{Ti}, \mathrm{Mg} \mathrm{Mn}, \mathrm{C}_{\text {tot }}$, and $\mathrm{S}_{\text {tot }}$ (Table 2). The content of the main components is quite invariable in all samples. High concentration of trace metals and toxic trace elements 
Fig. 2 Incineration residues formed after the incineration of sewage sludge and their annual mass production
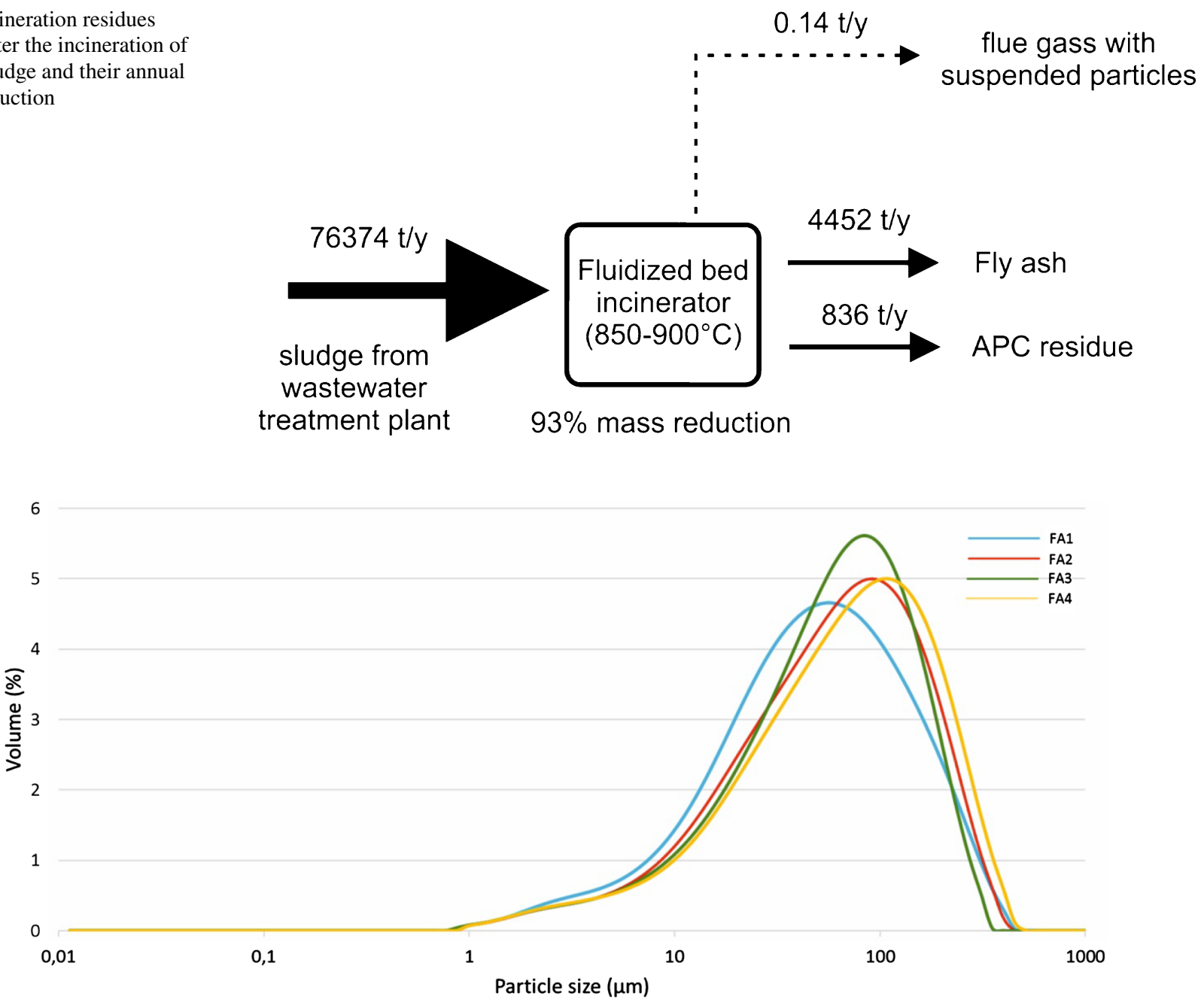

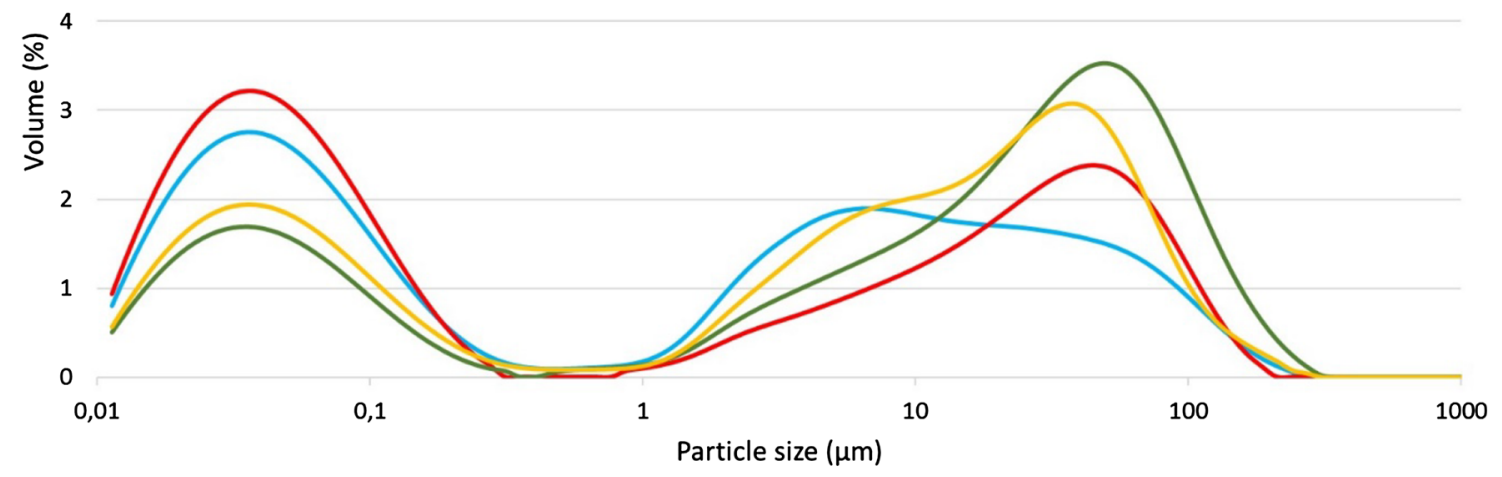

Fig. 3 Particle size distribution of the ISSA (a) and the APC residues (b) 
Table 2 The averaged annual content of ISSA and APC residues

\begin{tabular}{|c|c|c|c|c|c|c|c|c|c|c|c|c|}
\hline & $\begin{array}{l}\text { Average/ } \\
\text { Year }\end{array}$ & SD & $\mathrm{t} / \mathrm{FA} / \mathrm{y}$ & $\begin{array}{l}\text { Average/ } \\
\text { Year }\end{array}$ & SD & t/APC/y & $\begin{array}{l}\text { Average/ } \\
\text { Year }\end{array}$ & SD & t/APCp/y & $\begin{array}{l}\mathrm{FA}+\mathrm{APC} \\
\mathrm{t} / \mathrm{y}\end{array}$ & FA & APC \\
\hline & $\mathrm{FA} / \%$ & & 4452 & $\mathrm{APC} / \%$ & & 836 & APCp/\% & & 25 & 5288 & $\%$ & $\%$ \\
\hline $\mathrm{SiO}_{2}$ & 37.460 & 2.71 & 1667.719 & 0.4275 & 0.60 & 3.574 & 8.833 & 9.84 & 2.208 & 1671.293 & 99.79 & 0.21 \\
\hline $\mathrm{Al}_{2} \mathrm{O}_{3}$ & 8.023 & 0.49 & 357.162 & 0.0975 & 0.12 & 0.815 & 2.088 & 1.84 & 0.522 & 357.977 & 99.77 & 0.23 \\
\hline $\mathrm{Fe}_{2} \mathrm{O}_{3}$ & 14.315 & 1.41 & 637.304 & 0.1775 & 0.21 & 1.484 & 3.648 & 3.29 & 0.912 & 638.788 & 99.77 & 0.23 \\
\hline $\mathrm{MgO}$ & 3.663 & 0.14 & 163.055 & 0.0675 & 0.06 & 0.564 & 1.51 & 0.86 & 0.378 & 163.619 & 99.66 & 0.34 \\
\hline $\mathrm{CaO}$ & 12.093 & 1.53 & 538.358 & 0.56 & 0.39 & 4.682 & 13.075 & 8.41 & 3.269 & 543.04 & 99.14 & 0.86 \\
\hline $\mathrm{Na}_{2} \mathrm{O}$ & 0.698 & 0.05 & 31.053 & 45.645 & 1.21 & 381.592 & 1.475 & 0.58 & 0.369 & 412.645 & 7.53 & 92.47 \\
\hline $\mathrm{K}_{2} \mathrm{O}$ & 1.83 & 0.09 & 81.472 & 0.0425 & 0.04 & 0.355 & 0.363 & 0.48 & 0.091 & 81.827 & 99.57 & 0.43 \\
\hline $\mathrm{TiO}_{2}$ & 0.933 & 0.06 & 41.515 & 0.0175 & 0.02 & 0.146 & 0.27 & 0.23 & 0.068 & 41.661 & 99.65 & 0.35 \\
\hline $\mathrm{P}_{2} \mathrm{O}_{5}$ & 17.183 & 0.84 & 764.965 & 0.185 & 0.28 & 1.547 & 3.65 & 4.71 & 0.913 & 766.512 & 99.8 & 0.2 \\
\hline $\mathrm{MnO}$ & 0.108 & 0.01 & 4.7859 & 0.01 & 0.00 & 0.084 & 0.038 & 0.02 & 0.009 & 4.87 & 98.28 & 1.72 \\
\hline $\mathrm{C}_{\text {tot }}$ & 0.148 & 0.03 & 6.567 & 3.008 & 0.49 & 25.143 & 45.768 & 25.20 & 11.442 & 31.709 & 20.71 & 79.29 \\
\hline$S_{\text {tot }}$ & $\begin{array}{l}0.71 \\
\mathrm{mg} \mathrm{kg}^{-1}\end{array}$ & 0.08 & 31.609 & $\begin{array}{l}16.245 \\
\mathrm{mg} \mathrm{kg}^{-1}\end{array}$ & 1.30 & 135.808 & $\begin{array}{l}1.053 \\
\mathrm{mg} \mathrm{kg}^{-1}\end{array}$ & 0.27 & 0.263 & 167.417 & 18.88 & 81.12 \\
\hline $\mathrm{Ag}$ & 12.85 & 1.06 & 0.057 & 0.4 & 0.12 & $<0.001$ & 8.025 & 8.49 & $<0.001$ & 0.058 & 99.42 & 0.58 \\
\hline As & 13.975 & 1.88 & 0.062 & 0.9 & 0.42 & 0.001 & 8.75 & 5.49 & $<0.001$ & 0.063 & 98.81 & 1.19 \\
\hline $\mathrm{Au}^{*}$ & 737.575 & 110.45 & 0.003 & 3.225 & 3.16 & $<0.001$ & 8.85 & 24.68 & $<0.001$ & 0.003 & 99.92 & 0.08 \\
\hline $\mathrm{Ba}$ & 1262.25 & 130.63 & 5.62 & 21 & 26.17 & 0.018 & 462.25 & 333.01 & 0.012 & 5.637 & 99.69 & 0.31 \\
\hline $\mathrm{Bi}$ & 8.825 & 1.35 & 0.039 & 6.875 & 9.39 & 0.006 & 38.25 & 9.50 & 0.001 & 0.045 & 87.24 & 12.77 \\
\hline $\mathrm{Cd}$ & 5.625 & 0.99 & 0.025 & 0.4 & 0.06 & $<0.001$ & 7.75 & 8.64 & $<0.001$ & 0.025 & 98.68 & 1.32 \\
\hline $\mathrm{Ce}$ & 42.2 & 2.39 & 0.188 & 1.05 & 0.59 & 0.001 & 20.5 & 7.50 & 0.001 & 0.189 & 99.53 & 0.47 \\
\hline Co & 32.35 & 6.42 & 0.144 & 0.475 & 0.31 & $<0.001$ & 15.525 & 12.60 & $<0.001$ & 0.144 & 99.73 & 0.27 \\
\hline $\mathrm{Cr}$ & 795.15 & 213.35 & 3.54 & 20.52 & 13.68 & 0.017 & 205.2 & 226.86 & 0.005 & 3.5573 & 99.52 & 0.48 \\
\hline $\mathrm{Cu}$ & 639.3 & 46.31 & 2.846 & 19.55 & 12.40 & 0.016 & 315 & 216.50 & 0.008 & 2.863 & 99.43 & 0.57 \\
\hline $\mathrm{Hg}$ & 0.028 & 0.01 & $<0.001$ & 9.9425 & 1.30 & 0.008 & 50 & 0.00 & $<0.001$ & 0.008 & 1.46 & 98.54 \\
\hline $\mathrm{La}$ & 20.95 & 1.43 & 0.093 & 1.475 & 0.96 & 0.001 & 11.675 & 4.08 & $<0.001$ & 0.095 & 98.7 & 1.3 \\
\hline Mo & 21.475 & 3.00 & 0.01 & 1.05 & 0.26 & 0.001 & 3.025 & 2.43 & $<0.001$ & 0.096 & 99.09 & 0.91 \\
\hline $\mathrm{Nd}$ & 16.625 & 1.46 & 0.074 & 0.225 & 0.17 & $<0.001$ & 7.375 & 3.00 & $<0.001$ & 0.074 & 99.74 & 0.25 \\
\hline $\mathrm{Ni}$ & 97 & 17.82 & 0.432 & 3.225 & 2.44 & 0.003 & 42.825 & 22.92 & 0.001 & 0.435 & 99.38 & 0.62 \\
\hline $\mathrm{Pb}$ & 135.725 & 11.87 & 0.604 & 15.7 & 11.19 & 0.013 & 271.875 & 217.62 & 0.007 & 0.617 & 97.87 & 2.13 \\
\hline $\mathrm{Rb}$ & 53.525 & 3.31 & 0.238 & 0.675 & 1.14 & $<0.001$ & 10.775 & 14.42 & $<0.001$ & 0.239 & 99.76 & 0.24 \\
\hline $\mathrm{Sb}$ & 6.925 & 0.78 & 0.031 & 2.2 & 1.71 & 0.002 & 19.775 & 33.18 & $<0.001$ & 0.033 & 94.37 & 5.63 \\
\hline $\mathrm{Se}$ & 5.675 & 2.90 & 0.025 & 22.45 & 5.63 & 0.019 & 43.5 & 11.92 & 0.001 & 0.044 & 57.38 & 42.62 \\
\hline $\mathrm{Sn}$ & 340.75 & 137.88 & 1.517 & 22.25 & 30.05 & 0.019 & 715.75 & 1169.59 & 0.018 & 1.536 & 98.79 & 1.21 \\
\hline $\mathrm{Sr}$ & 521.375 & 25.03 & 2.321 & 14.825 & 9.38 & 0.012 & 328.65 & 141.28 & 0.008 & 2.334 & 99.47 & 0.53 \\
\hline V & 74.5 & 11.27 & 0.332 & 8 & 6.73 & 0.007 & 25.25 & 15.31 & 0.001 & 0.338 & 98.02 & 1.98 \\
\hline Y & 16.525 & 1.58 & 0.074 & 0.35 & 0.26 & $<0.001$ & 8 & 2.75 & $<0.001$ & 0.074 & 99.6 & 0.4 \\
\hline $\mathrm{Zn}$ & 3969.5 & 379.53 & 17.672 & 165 & 113.73 & 0.138 & 2896 & 2716.28 & 0.072 & 17.81 & 99.23 & 0.77 \\
\hline $\mathrm{Zr}$ & 279.9 & 45.42 & 1.246 & 3.6 & 4.01 & 0.003 & 76.575 & 69.86 & 0.002 & 1.249 & 99.76 & 0.24 \\
\hline
\end{tabular}

$S D$ standard deviation

were measured for $\mathrm{Zn}$, Ba, Cr, Cu, Sr, Sn, Zr, Pb, Ni, V, Co, Mo, and As (Table 2). For the Y, La, Ce, and Nd the concentrations are higher than $10 \mathrm{mg} \mathrm{kg}^{-1}$, whereas for the other REEs and other trace elements the concentrations do not exceed a few $\mathrm{mg} \mathrm{kg}^{-1}$. The high content of $\mathrm{Si}, \mathrm{Fe}, \mathrm{Ca}$, and Al with the exception of $P$ allows the ISSA to be considered as an alternative material for cement manufacture [12, 29], bricks and tiles [1, 37] or glass ceramics [36]. The LOI value for the ISSA on average is approximately $3.4 \mathrm{wt} \%$.

The main minerals determined in ISSA using XRD are quartz $(30 \pm 0.6 \mathrm{wt} \%)$, feldspar $(18.9 \pm 1.0 \mathrm{wt} \%)$, hematite $(7.8 \pm 0.4 \mathrm{wt} \%)$, whitlockite $(22 \pm 0.8 \mathrm{wt} \%)$, and $\mathrm{Fe}-\mathrm{PO}_{4}$ phase (PDF card 15-0655) (1.5 $\pm 0.3 \mathrm{wt} \%)$. The quartz grains are rounded or semi-rounded, feldspar grains are 
rather angular with signs of fragmentation along the cleavage planes (Fig. 4a, b, respectively). The hematite (Fig. 4c) is composed of microcrystals which are grouped into partly rounded assemblages, whereas the phosphates' grains are either perfectly rounded or in the form of compact spherulites or radial aggregates. The EDS analyses of different phosphates (Fig. 4d-f) indicate that they typically contain $\mathrm{Fe}, \mathrm{Mg}$, and $\mathrm{Ca}$ in different proportions. The presence of a fine-grained matrix surrounding bigger grains is common. This matrix is formed of a mixture of micro-grains, which in chemical composition are dominated by $\mathrm{Si}$ and $\mathrm{P}$, but they contain also $\mathrm{Ca}, \mathrm{Fe}, \mathrm{Al}, \mathrm{Mg}, \mathrm{K}$, and $\mathrm{Ti}$ (and sometimes $\mathrm{Na}$, $\mathrm{S}, \mathrm{Cl}, \mathrm{Mn}$, and $\mathrm{Ba}$ ). At the lower quantities Ti-Fe oxides (Fig. 4g), zircon (Fig. 4h), Fe-Cr-(Ni) alloys (Fig. 4i), and $\mathrm{Si}-\mathrm{Pb}-\mathrm{K}$ rich phases (Fig. 4j) are also found. The results of the quantitative XRD analyses using the Rietveld refinement method indicate that the content of amorphous phase is not very high $(19.9 \pm 2.4 \mathrm{wt} \%)$. The mineral composition of the ISSA can vary for different plants; however, but in many publications the above-mentioned mineral phases are common [e.g. 8, 10,11, 19], with the only differences being in their amount and the morphology.

The APC residues comprise light gray, very fine material, where particles below $100 \mu \mathrm{m}$ constitute over $95 \mathrm{vol} \%$, and the water-soluble material content is ca. $98 \mathrm{wt} \%$. The bimodal particle size distribution (Fig. 3b) with modes at $0.03 \mu \mathrm{m}$ and $45.61 \mu \mathrm{m}$ were measured for APC2 and APC3 samples, whereas in sample APC4, apart from the modes observed in previous samples a shoulder to the left of the second mode (at $6.72 \mu \mathrm{m}$ ) was also observed (Fig. 3b). In sample APC1, two modes were observed-at $0.03 \mu \mathrm{m}$ and at $6.72 \mu \mathrm{m}$, and a shoulder to the right at $21.21 \mu \mathrm{m}$ and $45.61 \mu \mathrm{m}$. The APC residues' composition is dominated by Na-rich water soluble phases. The Na content is the highest, together with high $\mathrm{S}_{\text {tot }}$ concentrations, indicating the presence of sodium sulphates. In addition, the high $\mathrm{C}_{\text {tot }}$ content may indicate the presence of either carbonate minerals or unburned organic material. As suggested by Donatello and Cheesman [12], the LOI value can indicate the unburned carbon content.

Trace elements ( $\mathrm{Zn}, \mathrm{Se}, \mathrm{Sn}, \mathrm{Ba}, \mathrm{Cr}, \mathrm{Cu}, \mathrm{Pb}, \mathrm{Sr}$, and $\mathrm{Hg}$ ) are highly concentrated (Table 2). Nevertheless, the concentrations of these elements in the APC residues are already several times lower than in the ISSA. The removal of water soluble phases from the APC residues by dissolution in deionised water caused significant mass reduction of $98 \%$, and additional concentration of elements occurring in nonsoluble phases ( $\mathrm{Zn}, \mathrm{Sn}, \mathrm{Ba}, \mathrm{Sr}, \mathrm{Cu}, \mathrm{Pb}$, and $\mathrm{Cr}$, and also $\mathrm{Hg}$, $\mathrm{Se}, \mathrm{Ni}, \mathrm{Bi}, \mathrm{V}, \mathrm{Ce}, \mathrm{Sb}, \mathrm{Co}$, and $\mathrm{La}$ ).

The mineral composition of the APC residues is strongly dependent on the waste feed composition, the used technology, the type of incinerator and the APC system [31], as well as the intensity of the processes that occur during and after incineration such as melting, vaporization, crystallization or vitrification. The dominant mineral phases in the APC residues are thenardite $(40.1 \pm 0.8 \mathrm{wt} \%)$ (Fig. $5 \mathrm{a})$, thermonatrite $(12.7 \pm 1.0 \mathrm{wt} \%)$ (Fig. 5a), and apatite $(13.8 \pm 0.7 \mathrm{wt} \%)$, while whitlockite $(9.3 \pm 0.7 \mathrm{wt} \%)$, anhydrite $(3.9 \pm 0.3 \mathrm{wt} \%)$, calcite $(2.8 \pm 0.7 \mathrm{wt} \%)$, halite $(2.5 \pm 0.3 \mathrm{wt} \%)$, and gypsum $(2.2 \pm 0.4 \mathrm{wt} \%)$ are also present in lower amounts. In the APC residues, the amorphous phase content is much lower than in the ISSA and equals $12.7 \pm 2.3 \mathrm{wt} \%$. After the removal of water soluble fraction by dissolution in deionized water, calcite $(22.3 \pm 1.0 \mathrm{wt} \%)$, whitlockite $(13.9 \pm 1.3 \mathrm{wt} \%)$, thénardite $(6.3 \pm 1.2 \mathrm{wt} \%)$, hematite $(5.8 \pm 0.6 \mathrm{wt} \%)$, and quartz and halite $(1.5 \pm 0.6 \mathrm{wt} \%$ each) were detected in the APC residues. In the insoluble part of the APC residues the content of amorphous phase was high $(45.1 \pm 3.2 \mathrm{wt} \%)$, and within the range obtained by other authors $[2,30]$. The SEM-EDS results are consistent with the XRD analyses. $\mathrm{Si}-\mathrm{Pb}-\mathrm{K}$ rich phases (Fig. 5b), Ca-phosphates with $\mathrm{Sn}$ (Fig. 5c), pyrite (Fig. 5d), anhydrite, hematite (Fig. 5e), and feldspar (Fig. 5f) grains are also detected. LOI content is on average $6.6 \mathrm{wt} \%$, which can indicate inefficient sludge combusion. Sludge is considered to be efficiently incinerated when the LOI value is lower than $3 \mathrm{wt} \%$ [12].

The extractable organic matter content in both the ISSA and the APC residues' samples is very low. The ISSA sample yielded $0.003 \mathrm{mg}$ extract/g sample $(0.28 \mathrm{wt} \%$ extract/ total carbon), whereas the APC residues' sample yielded $0.992 \mathrm{mg}$ extract/g sample (3.03 wt\% extract/total carbon). The molecular composition is very poor, dominated by free carboxylic acids as $\mathrm{C}_{16}$ and $\mathrm{C}_{18}$ normal saturated monocarboxylic acids, which are most probably contaminations (e.g. from solvents). Therefore, we assume that the high LOI value in the APC residues is not related to the inefficient combustion of the sludge, as suggested by Donatello and Cheesman [12], but rather due to the presence of minerals that contain water in their structure, such as thermonatrite, gypsum or apatite. Carbon was also detected in the EDS analyses, and thus the presence of organic matter in the form of carbon characterized by a different degree of coalification or non-extractable inert organic substance that is preserved after incineration cannot be excluded. For further investigations of the organic matter composition, different extraction procedures should be taken into consideration.

\section{Partitioning of elements and mass flow calculations}

As mentioned above, the particle size distribution is important for elements' accumulation. Li et al. [20] indicate that along with the decreasing particle size distribution the concentration of elements, which are considered as toxic, increases. Several authors have already attempted to evaluate the relation between the particle size distribution and the elements' concentration. Liao et al. [21 and references therein] 
Fig. 4 SEM images of the main and metallic components in ISSA with their most typical morphologies: a rounded quartz (Qz) grains, in the picture also elongated, rectangular zircon ( $\mathrm{Zrn})$ is present and $\mathrm{Mg}$-phosphate $\left(\mathrm{Mg}-\mathrm{PO}_{4}\right)$ that looks like porous sinter and $\mathrm{Fe}$ phosphate $\left(\mathrm{Fe}-\mathrm{PO}_{4}\right)$ in a radial form; b K-feldspar (K-Fsp) with visible cleavage; $\mathbf{c}$ iron oxide (Fe ox) with rounded edges; $\mathbf{d}$ porous sinter-like Fe phosphate; e radial phosphate of $\mathrm{Fe}$ and $\mathrm{Mg}$ (Fe,Mg-PO), which also contains a small amount of $\mathrm{Ca}$ in the EDS spot analyses; $\mathbf{f}$ radial, porous $\mathrm{Mg}$ phosphate; g Fe-Cr and Ti-Fe alloys, both with rounded edges surrounded by iron oxides ( $\mathrm{Fe}$ ox) and a grain of Fe-ox composed of microcrystals; $\mathbf{h}$ sharp-edged $\mathrm{Si}-\mathrm{Pb}-\mathrm{K}$ rich phases $(\mathrm{Si}-$ $\mathrm{Pb}-\mathrm{K})$, cracked quartz $(\mathrm{Qz})$ grains and metallic iron $(\mathrm{Fe})$ in the irregular form; $\mathbf{i}$ tabular, blocky galena $(\mathrm{PbS})$, rounded zircon (Zrn) and matrix, usually composed of $\mathrm{Si}, \mathrm{Al}, \mathrm{P}, \mathrm{Ca}, \mathrm{Fe}$, $\mathrm{K}, \mathrm{Mg}$, and $\mathrm{Na}$ in variable proportions, often overgrown with organic material (org); j variability of $\mathrm{Fe}, \mathrm{Ni}$, and $\mathrm{Cr}$ alloys depending on the dominant elements, barite (Brt)
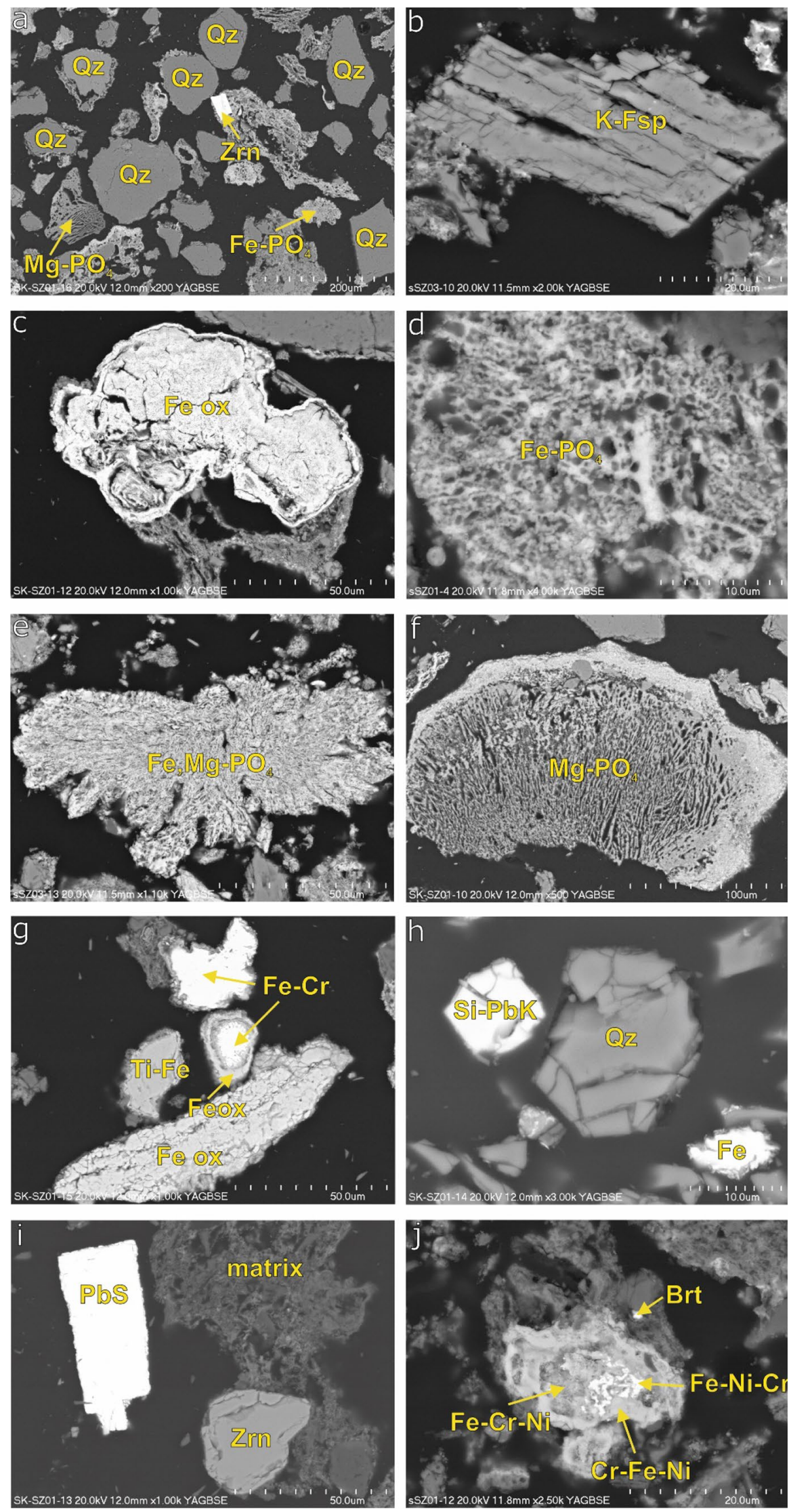
Fig. 5 SEM images of the main and metallic components in the APC residues: a crystals of thenardite (Thn) precipitated from the solution obtained from soluble material removal in the form of bone-like assemblages and thermonatrite (Thr) in the form of pyramids; $\mathbf{b}$ sharpedged $\mathrm{Si}-\mathrm{Pb}-\mathrm{K}$ rich phases $(\mathrm{Si}-$ $\mathrm{Pb}-\mathrm{K}$ ) with visible cracks and quartz (Qz) grains surrounded by remnants of organic matter (org); c rounded assemblage of iron oxide (Fe ox) composed of elongated microcrystals; $\mathbf{d}$ rounded calcium phosphate, probably whitlockite $\left(\mathrm{Ca}-\mathrm{PO}_{4}\right)$ with $\mathrm{Sn}$-Ti intersitions; e iron sulfide (FeS) cracked or composed of sharp-edged microcrystals gathered together; $\mathbf{f}$ plagioclase (Fsp) cracked along the cleavage and surrounded by K-feldspar (K-Fsp)
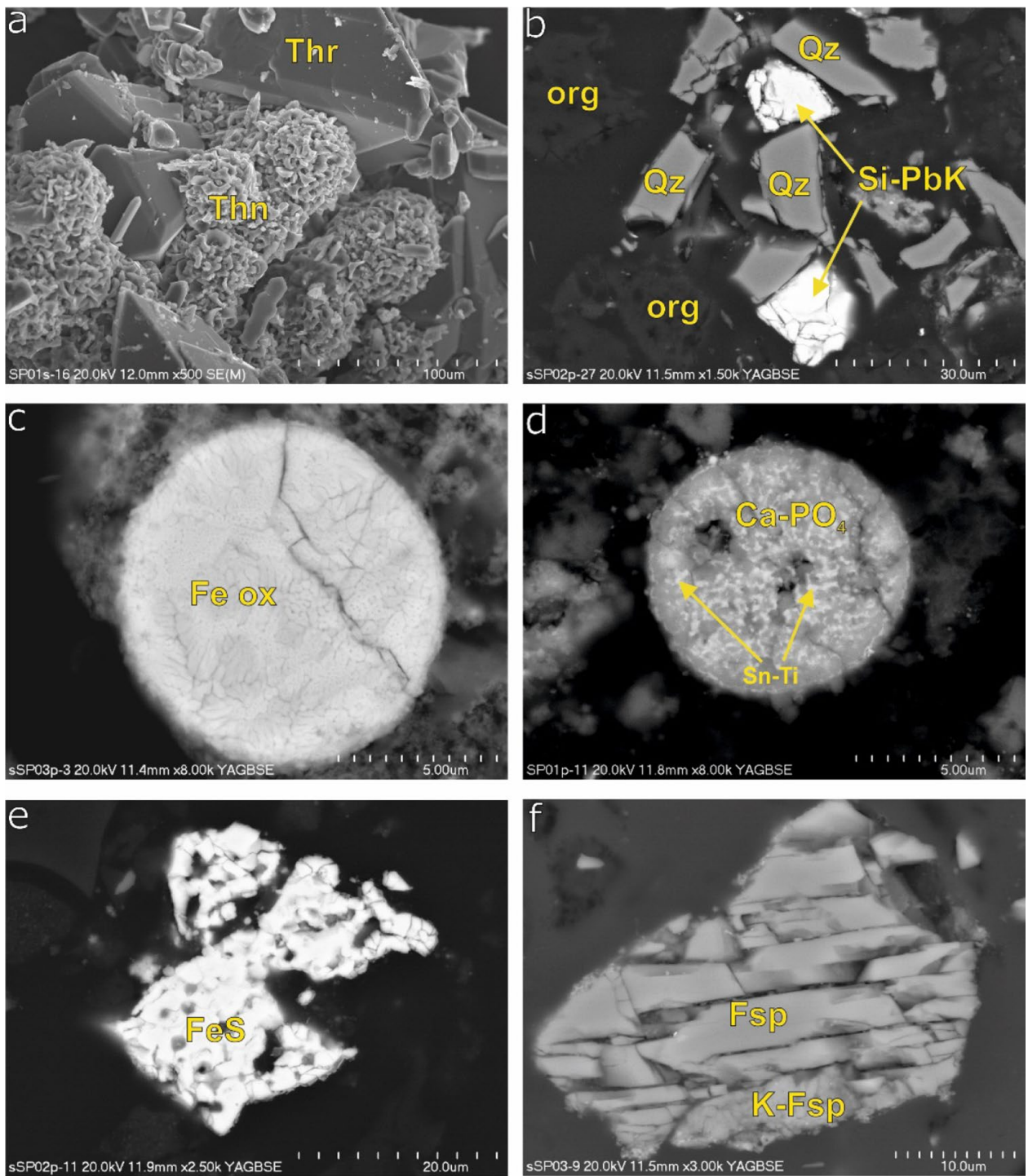

show that most of the trace elements, however, economically valuable (e.g. $\mathrm{Zn}, \mathrm{Cu}, \mathrm{Pb}, \mathrm{Cd}, \mathrm{Mo}, \mathrm{As}, \mathrm{Ba}$, and $\mathrm{Sn}$ ) are concentrated in the particles whose size is in the range of $50-125 \mu \mathrm{m}$, whereas $\mathrm{Cr}$ is mostly found in the fraction from 125 to $250 \mu \mathrm{m}$. These results allow us to assume that most of the elements are gathered in the ISSA, in which most of the particles are within the aforementioned size range. The APC residues are characterized by much smaller particles; however, many of them are also in the given range. The particle size distribution can give us a first hint of the partitioning of elements during incineration.

The fractionation of elements is a function of the volatility of elements. Following the work of [6, 22, 25, 32] the volatility of elements in coal-fired boilers and in coal combustion between the bottom ash (BA) and ISSA was described. Low volatile elements (REEs, Y, Sc, Hf, Mn, Rb, $\mathrm{Th}$, and $\mathrm{Zr}$ ) are distributed equally between BA and ISSA, $\mathrm{Zn}$ and As are enriched in ISSA in comparison to their content in $\mathrm{BA}$, whereas $\mathrm{Hg}, \mathrm{Se}$, and $\mathrm{B}$ are the most volatile and concentrated in the ISSA. Some of these elements can overlap depending, for example, on the combustion conditions and combustor type, which can cause different ranges of volatility of the elements, as well as fluid dynamics and kinetic factors within the incinerator [12]. In addition, elements can concentrate more easily on smaller particles [24, $39]$ owing to the high surface area of fine particles. Due to the fact that in the discussed fluidized-bed boilers BA is not produced, the studied sewage sludge partitioning of elements is described for the ISSA and the APC residues characterized by very fine fraction. Kasina et al. [17] suggest that the partitioning of elements in the ISSA and the APC residues depends mostly on their melting temperatures. Elements characterized by high melting temperature (Mo, $\mathrm{Cr}$, $\mathrm{Ti}, \mathrm{Fe}, \mathrm{Ni}, \mathrm{Co}, \mathrm{Mn}$, and $\mathrm{Au}$ ) are mostly concentrated in the ISSA. As, $\mathrm{Zn}$, and $\mathrm{Cu}$ are distributed evenly between both residues, whereas those of lower melting temperatures $(\mathrm{Hg}$, 
$\mathrm{Se}, \mathrm{Sb}, \mathrm{Sn}, \mathrm{Pb}$, and $\mathrm{Cd}$ ) could be released from the boiler in a volatile form, and thus are concentrated in the APC residues.

Material mass flows' calculations (the mass of a given material per year) and the results of the chemical analysis give the possibility for the evaluation of the possible recovery of highly concentrated elements in the ISSA and the APC residues. The mass flows are calculated by normalizing the concentration of each element in a given stream with the corresponding stream for the entire installation under consideration. The results of these calculations are listed in Table 2.

Elements highly concentrated in incineration residues are distributed unequally between the ISSA and the APC residues. Dominating elements such as $\mathrm{Si}, \mathrm{Fe}, \mathrm{Ca}, \mathrm{P}$, and $\mathrm{Al}$ are accumulated in the ISSA to the amount of 2,230 tons per year, comprising over $42 \%$ of all elements present in the incineration residues from the analyzed installation. Noteworthy is the high concentration of phosphorus, which is an important, however, non-renewable resource. In addition, in the EU countries, there is a lack of economically viable phosphate reserves, and thus the recognition and recovery of phosphorus from alternative sources such as incineration ashes would seem to be of importance. Over $17 \mathrm{wt} \%$ of $\mathrm{P}_{2} \mathrm{O}_{5}$ is accumulated on average in the ISSA, giving almost 750 tons annually that can be recovered (assuming $100 \%$ effectivity of recovery) and only 1.5 tons per year is accumulated in the APC residues.

Even though over $90 \%$ of $\mathrm{Na}$ is accumulated in the APC residues, the concentration does not exceed $640 \mathrm{~kg}$ per year in the incineration residues, and its recovery for industrial purposes does not seem to be justified, especially we have to keep in mind that most of this element was added to the system in the form of sodium bicarbonate (Fig. 6a) during the purification of the exhaust gasses, and therefore, caused abnormal accumulation of this element.

A total of $99 \%$ of the REEs, which are known to be characterized by low volatility [22], are accumulated in the ISSA; however, their concentrations are very low, and far below the average composition of the upper continental crust [34]. Ce, La, Nd, and Y are of the highest concentrations, but in the 5,288 tons of annually produced residues the content of $\mathrm{Ce}$ is $187 \mathrm{~kg}$, of $\mathrm{La}$ is $93 \mathrm{~kg}$, of $\mathrm{Nd}$ is $4 \mathrm{~kg}$, and of $\mathrm{Y}$ is $73 \mathrm{~kg}$.

The measured concentrations of $\mathrm{Cd}, \mathrm{Cr}, \mathrm{Cu}, \mathrm{Ni}$, and $\mathrm{Zn}$ indicate their accumulations in the ISSA, while $\mathrm{Hg}, \mathrm{Pb}, \mathrm{Sn}$, $\mathrm{Sb}, \mathrm{Bi}$, and $\mathrm{Se}$ are concentrated mostly in the insoluble part of the APC residues, which are precipitated as a result of the addition of $\mathrm{NaHCO}_{3}$ in the purification process of the exhaust gasses; whereas the mass flow calculations indicate that $99 \%$ of $\mathrm{Mo}, \mathrm{Cd}, \mathrm{Cr}, \mathrm{Cu}$ (Fig. 6b), Ni, Sn, and Zn, as well as over $97 \%$ of $\mathrm{Pb}, 94 \%$ of $\mathrm{Sb}$, and $87 \%$ of $\mathrm{Bi}$ accumulate in the ISSA, comprising a total of 25.5 tons per year. Se is fractionated more or less evenly between the ISSA and the APC residues (ca. $25 \mathrm{~kg}$ per year and $18 \mathrm{~kg}$ per year, respectively), whereas $99 \%$ of $\mathrm{Hg}(\sim 1 \mathrm{~kg}$ per year in the total amount of residues produced annually; Fig. $6 \mathrm{c})$ is concentrated in the APC residues.

\section{Conclusions}

1. The valuable elements accumulated in the sewage sludge incineration residues in the studied installation are dispersed within components of very fine-grained matrix and in small grains of minerals and amorphous substances. Their presence in the form of discrete grains of own phases (e.g. minerals and alloys) is rare and their size hardly exceeds $10 \mu \mathrm{m}$.

2. The small particle size can favor the accumulation and enrichment of some elements in the sewage sludge incineration residues.

3. Elements which are characterized by high melting temperatures concentrate in the ISSA, while elements that are characterized by lower melting temperatures (e.g. Sn and $\mathrm{Hg}$ ) concentrate in the APC residues. The As, $\mathrm{Zn}$, and $\mathrm{Cu}$ are distributed evenly between the ISSA and the APC residues.

4. The concentration of metallic elements is quite high. In the ISSA, the annual average concentration is around $16 \mathrm{wt} \%$; however, this is $14 \mathrm{wt} \%$ for Fe. In the APC residues, the total content of metallic elements is much lower and barely exceeds $2 \mathrm{wt} \%$.
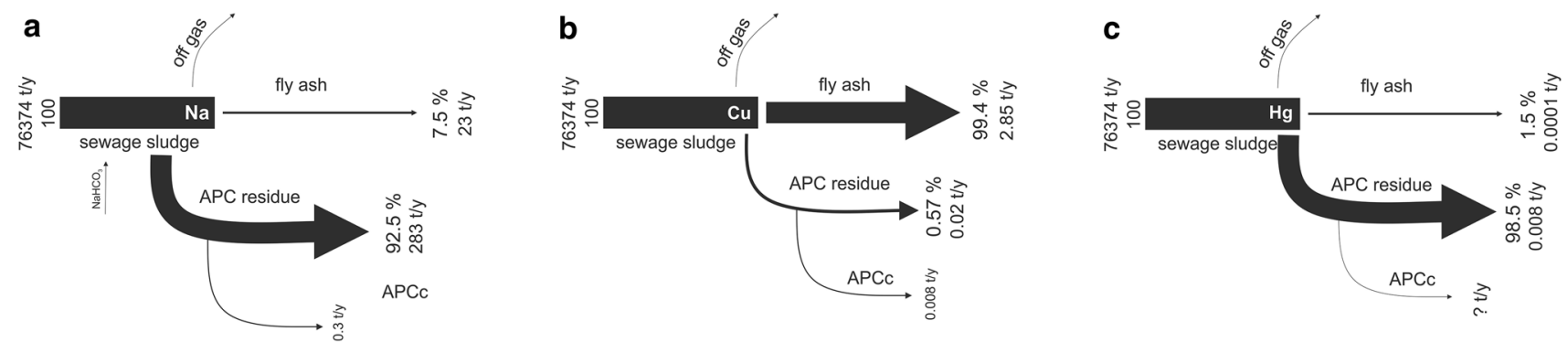

Fig. 6 Mass flow calculations (mass per year) for $\mathbf{a} \mathrm{Na} ; \mathbf{b ~} \mathrm{Cu} ; \mathbf{c ~} \mathrm{Hg}$ 
5. The content of elements gives us important information about the composition of residues, but is not a reliable indicator of their recovery potential.

6. The content of valuable elements recalculated on the produced waste mass of the incineration residues and their extraction is currently not economically feasible for studied samples. Taking into consideration that the amount of sewage sludge incineration residues will increase significantly in the near future, and the resources of ores and natural raw material will be reduced or limited, while if we take into consideration the costs of exploitation or mining, mineral processing, and other technical costs such as infrastructure, environmental and social costs on the one hand, and easily accessible, cheap material that does not require complicated processing methods on the other, ISSA can be considered as an important waste-based source of economically important elements (i.e. $\mathrm{P}, \mathrm{Zn}, \mathrm{Sn}, \mathrm{Cr}, \mathrm{Pb}, \mathrm{Au}$, and $\mathrm{Ag}$ ).

Acknowledgements The study was supported by the Polish National Science Centre (NCN) through Grant no. UMO-2014/15/B/ ST10/04171.

Open Access This article is distributed under the terms of the Creative Commons Attribution 4.0 International License (http://creativeco mmons.org/licenses/by/4.0/), which permits unrestricted use, distribution, and reproduction in any medium, provided you give appropriate credit to the original author(s) and the source, provide a link to the Creative Commons license, and indicate if changes were made.

\section{References}

1. Anderson M (2002) Encouraging prospects for recycling incinerated sewage sludge ash (ISSA) into clay-based building products. J Chem Technol Biotechnol 77:352-360

2. Bodénan F, Deniard P (2003) Characterization of flue gas cleaning residues from European solid waste incinerators: assessment of various Ca-based sorbent processes. Chemosphere 51:335-347. https://doi.org/10.1016/S0045-6535(02)00838-X

3. Bujak J (2015) Thermal treatment of medical waste in a rotary kiln. J Environ Manag 162:139-147. https://doi.org/10.1016/j. jenvman.2015.07.048

4. Chakraborty S, Jo B, Jo J, Baloch Z (2015) Effectiveness of sewage sludge ash combined with waste pozzolanic minerals in developing sustainable construction material: an alternative approach for waste management. J Clean Prod 153:253-263. https://doi. org/10.1016/j.jclepro.2017.03.059

5. Chandler AJ, Eighmy TT, Hartlén J, Hjelmar O, Kosson DS, Sawell SE, van der Sloot HA, Vehlow J (1997) Municipal solid waste incineration residues. Studies in Environmental Science 67. ISBN: 978-0-444-82563-6

6. Clarke LB, Sloss LL (1992) Trace elements: emissions from coal combustion and gasification, report EEACR/49 k, IEA Coal Research, London, p 111

7. The Council Directive 199/31/EC of 26 April 1999 on the landfill of waste
8. Cyr M, Coutand M, Clastres P (2007) Technological and environmental behaviour of sewage sludge ash (SSA) in cementbased materials. Cem Concr Res 37:1278-1289. https://doi. org/10.1016/j.cemconres.2007.04.003

9. Directive 2000/76/Ec of the European Parliament and of the Council of 4 December 2000 on the incineration of waste

10. Donatello S, Freeman-Pask A, Tyrer M, Cheeseman C (2010) Effect of milling and acid washing on the pozzolanic activity of incinerator sewage sludge ash. Cem Concr Compos 32:54-61. https://doi.org/10.1016/j.cemconcomp.2009.09.002

11. Donatello S, Tyrer M, Cheeseman C (2010) EU landfill waste acceptance criteria and EU hazardous waste directive compliance testing of incinerated sewage sludge ash. Waste Manag 30:63-71. https://doi.org/10.1016/j.wasman.2009.09.028

12. Donatello S, Cheeseman C (2013) Recycling and recovery routes for incinerated sewage sludge ash (ISSA): a review. Waste Manag 33:2328-2340. https://doi.org/10.1016/j.wasma n.2013.05.024

13. Eriksson E, Christensen N, Schmidt JE, Ledin A (2007) Potential priority pollutants in sewage sludge. Desalination $226: 371-$ 388. https://doi.org/10.1016/j.desal.2007.03.019

14. European Commission (2015) Closing the loop—an EU action plan for the Circular Economy, COM 614, final

15. Fytili D, Zabaniotou A (2008) Utilization of sewage sludge in EU application of old and new methods - a review. Renew Sust Energy Rev 12:116-140. https://doi.org/10.1016/j. rser.2006.05.014

16. Grabowski Z (2011) Incineration of sewage sludge based on STUO Krakow. Fourth forum of the sludge management

17. Kasina M, Kowalski PR, Michalik M (2016) Metals accumulation during thermal processing of sewage sludge-characterization of fly ash and air pollution control (APC) residues. Energy Procedia 97:23-30. https://doi.org/10.1016/j.egypr o.2016.10.012

18. Kasina M, Kowalski PR, Michalik M (2017) Seasonal changes in chemical and mineralogical composition of sewage sludge incineration residues and their potential for metallic elements and valuable components recovery. Energy Procedia 125:34-40. https:// doi.org/10.1016/j.egypro.2017.08.049

19. Li R, Teng W, Li Y, Wang W, Cui R, Yang T (2017) Potential recovery of phosphorus during the fluidized bed incineration of sewage sludge. J Clean Prod 140:964-970. https://doi. org/10.1016/j.jclepro.2016.06.177

20. Li Y, Cui R, Yang T, Zhai Z, Li R (2017) Distribution characteristics of heavy metals in different size fly ash from a sewage sludge circulating fluidized bed incinerator. Energy Fuels 31:2044-2051. https://doi.org/10.1021/acs.energyfuels.6b02676

21. Liao C, Wu C, Yan Y (2007) The characteristic of inorganic elements in ashes from a 1 MW CFB biomass gasification power generation plant. Fuel Process Technol 88:149-146. https://doi. org/10.1016/j.fuproc.2005.06.008

22. Liu J, Dai S, He X, Hower JC, Sakulpitakphon T (2017) Sizedependent variations in fly ash trace element chemistry: examples from a Kentucky power plant and with emphasis on rare earth elements. Energy Fuels 31:438-447. https://doi.org/10.1021/acs. energyfuels.6b02644

23. Lynn CJ, Dhir RK, Ghataora GS, West RP (2015) Sewage sludge ash characteristics and potential for use in concrete. Constr Build Mater 98:767-779. https://doi.org/10.1016/j.conbuildma t.2015.08.122

24. Mardon SM, Hower JC (2004) Impact of coal properties on coal combustion by-product quality: examples from a Kentucky power plant. Int J Coal Geol 59:153-169. https://doi.org/10.1016/j. coal.2004.01.004 
25. Meij R (1994) Trace element behavior in coal fired power plants. Fuel Process Technol 39:199-217. https://doi.org/10.1016/03783820(94)90180-5

26. Menéndez JA, Inguanzo M, Pis JJ (2002) Microwave-induced pyrolysis of sewage sludge. Water Res 36:3261-3264. https:// doi.org/10.1016/S0043-1354(02)00017-9

27. Mladenovič A, Hamler S, Zupančič N (2017) Environmental characterisation of sewage sludge/paper ash-based composites in relation to their possible use in civil engineering. Environ Sci Pollut Res Int 24:1030-1041. https://doi.org/10.1007/s11356-016-78432

28. Oros DR, Simoneit BRT (2000) Identification and emission rates of molecular tracers in coal smoke particulate matter. Fuel 79:515-536

29. Pan S-Ch, Lee TD-H Ch-Ch, Lee Ch (2003) Influence of the fineness of sewage sludge ash on the mortar properties. Cem Concr Res 33:1749-1754. https://doi.org/10.1016/S0008-8846(03)00165 $-0$

30. Quina MJ, Santos RC, Bordado JC, Quinta-Ferreira RM (2008) Characterization of air pollution control residues produced in a municipal solid waste incinerator in Portugal. J Hazard Mater 152:853-869. https://doi.org/10.1016/j.jhazmat.2007.07.055

31. Rani DA, Boccaccini AR, Deegan D, Cheeseman CR (2008) Air pollution control residues from waste incineration: current UK situation and assessment of alternative technologies. Waste Manag 28:2279-2292. https://doi.org/10.1016/j.wasman.2007.10.007

32. Ratafia-Brown JA (1994) Overview of trace element partitioning in flames and furnaces of utility coal-fired boilers. Fuel Process Technol 39:139-157. https://doi.org/10.1016/0378-3820(94)90177-5
33. Rozumová L, Motyka O, Čabanová K, Seidlerová J (2015) Stabilization of waste bottom ash generated from hazardous waste incinerators. J Environ Chem Eng 3:1-9. https://doi.org/10.1016/j. jece.2014.11.006

34. Rudnick R, Gao S (2003) The Crust, 3.01 - The composition of the continental crust. In: Holland HD, Turekian KK (eds) Treatise on geochemistry, vol 3. Elsevier-Pergamon, Oxford, pp 1-64. https://doi.org/10.1016/b0-08-043751-6/03016-4

35. Stasta P, Boran J, Bebar L, Stehlik P, Oral J (2005) Thermal processing of sewage sludge. Appl Therm Eng 26(13):1420-1426. https://doi.org/10.1016/j.applthermaleng.2005.05.030

36. Suzuki S, Tanaka M, Kaneko T (1997) Glass-ceramic from sewage sludge ash. J Mater Sci 32:1775-1779

37. Tay JH (1987) Bricks manufactured from sludge. J Environ Eng ASCE 113:278-283

38. The European List of Waste (2008). Commission Decision 2000/532/EC and Annex III to Directive 2008/98/EC

39. Wilczyńska-Michalik W, Moryl R, Sobczyk J, Michalik M (2014) Composition of coal combustion by-products: the importance of combustion technology. Fuel Process Technol 124:35-43. https:// doi.org/10.1016/j.fuproc.2014.02.016

Publisher's Note Springer Nature remains neutral with regard to jurisdictional claims in published maps and institutional affiliations. 